$\frac{\text { Jpn. J. Pharm. Health Care Sci. }}{\text { ノ ー }}$

\title{
日本の薬剤師卒後教育の問題点と改善点
}

\author{
山口 巧*，末丸克矢，荒木博陽 \\ 愛媛大学医学部附属病院薬剂部
}

\section{Problems in Continuing Education for Japanese Pharmacists and their Resolution}

\author{
Takumi Yamaguchi*, Katsuya Suemaru and Hiroaki Araki \\ Division of Pharmacy, Ehime University Hospital
}

$\left[\begin{array}{l}\text { Received July 26, } 2004 \\ \text { Accepted September 15, 2004 }\end{array}\right]$

\begin{abstract}
Faculties of pharmaceutical science in Japan are to start six-year curriculums in 2006 and this reform of the educational system is expected to further improve the quality of pharmaceutical care provided by pharmacists. However, the improvement of education for pharmacists who have already received their license is as important as changing to the six-year curriculum. To obtain ideas for improving education for Japanese pharmacists in the future, we investigated the American Pharmacist Continuing Education System in the state of Ohio. We also sent out a questionnaire on Pharmacist Education to all members of the Ehime Society of Hospital Pharmacists. The questionnaire was based on the results of our investigation of the Ohio State system. Through it, we found that many pharmacists feel dissatisfied with the current pharmacist education system. A particular point of dissatisfaction was that many respondents felt they were too busy time to attend lecture meetings and were therefore interested in education via the Internet. Thus, an important finding of our questionnaire survey was that the establishment of active learning systems using the Internet would meet the needs of Japanese pharmacists who have already received their license.
\end{abstract}

Key words - six-year curriculum, active education, Internet, continuing pharmacist education

\section{緒言}

現在，日本の医療における「質の向上」が問われてお り, 薬剤師業務に関しても例外ではない。さらに薬学教 育の改善, 充実に関する調査研究協力者会議の中で「医 療の質の改善が求められる中では, 特に医療人としての 質の高い薬剂師養成が必要」とうたっている。この概念 の元, 平成18年度より日本においても薬学部 6 年制が採 用されることが決定された1).

米国では, すでに薬剤師養成のための学部教育に 6 年 制を実施しており,さらに優れた卒後教育, 研修により 「質の高い薬剤師」が他の医療人にも広く認知されてい る ${ }^{2)}$. 加えて, 米国では薬剂師免許を発行する州毎に免 許更新義務として, 薬剂師継続教育制度 (Continuing Education)が制定されている。米国薬剂師全体の知識, 教育 レベルの高さを支えているのは，この薬剤師継続教育制 度といっても過言ではない.もちろん,このような厳し
い教育制度をクリアするために必要な教育材料，特にイ ンターネットを利用した無料の薬剤師教育サイトの充 実，卒後研修機関ならびにその実施団体の充実は目を見 はるものがある。

一方，日本における現在の薬剂師卒後教育において は, 各種団体, あるいは薬学系大学での講演形式で実施 される教育が主な教育源である。「質の高い医療」に携 わる薬剂師として現役の薬剤師が自己研鑽を積むことが 重要であることはいうまでもない. そのためにも将来の 薬学部教育 6 年制への変革に伴い, 現役薬剂師の卒後教 育の変勒極めて重要となると考えられる.

著者は「平成15年度厚生労働科学研究費補助金による 医薬品等医療技術リスク評価研究推進事業」で平成15年 11月から平成16年 3 月まで米国オハイオ州にて米国薬剤 師卒後教育の状況を調査した。ささらに, 愛媛県の病院薬 剂師らを対象に「薬剤師卒後教育」に関するアンケート 調査を実施した。われわれは，その結果と米国での薬剤 師卒後教育調査に基づいて, 今後の日本における薬剤師 
卒後教育の在り方について考察した。

\section{方法}

\section{1. 米国オハイオ州薬剂師継続教育制度に関する調査}

「平成15年度医薬品等医療技術リスク評価研究推進事 業」(期間：2003年11月～2004年 3 月）に打いてルイス． ストークス退役軍人病院クリーブランド部門薬剂部の協 力のもと米国オ八イオ州に扔ける薬剂師免許制度, 薬剤 師継続教育制度ならびに米国薬郕師卒後教育方法に関し て調査・討議し, 日本に押ける各薬剂師制度の現状と比 較検討した。

\section{2. 愛媛県現役薬剤師に対する薬剤師卒後教育に関する 意識調查}

2004年 5 月現在で愛媛県病院薬剤師会に所属している 全薬剂師(計127施設：病院勤務薬剂師470名, 保険薬局 薬剂師47名, その他 3 名, 計520名) に対して薬剤師教育 に関するアンケート調査(Fig. 1)を実施した。な掞，ア ンケートは無記名の選択方式とし，アンケートの実施と 内容については事前に愛媛県病院薬剂師会の了承を得 た.

得られた回答はその内容を集計し，回答者の年齢と性 別での比較検討を行った。 な扔, 年齢もしくは性別に関 する回答がないものに関しては, 各項目の年齢分析もし くは性別分析の結果からは除外した。

\section{結果}

\section{1. 米国オハイオ州薬剤師継続教育制度に関する調查}

米国に㧈ける薬剂師免許制度と日本に扔ける薬剂師免
許制度の相違について Table 1 に示した。また，米国に 扔ける各研修・教育と資格制度に係わる組織・機関の一 覧およびその略号一覧を Table 2 に示した。

\section{2. 愛媛県現役薬剤師に対する薬剤師卒後教育に関する}

\section{意識調査}

1) アンケートの回收率と回答者の背景

アンケート調査の結果, 360名 (回収率69.2\%)の回答 を得た。回答者の個人背景を Fig. $2 \mathrm{~A}, \mathbf{B}$ に示す. 回答 者の男女比率は女性が $64 \%$, 男性は35\%であった。一 方，10歳毎の年齢別構成比率は20代が $29 \%, 30$ 代が 26\%，40代が25\%，50代以上は19\%であった。

2 ) 現在の薬剤師卒後教育に関するアンケート調査 「薬剤師業務に抒ける自己研鑽の必要性」に関する質 問に対して, 全回答者が「必要である」と回答した。ま た, 自己研鑽の方法に関しては,「病院薬剤師会等によ る講演会等」(86.9\%)拈よび「医療系雑誌, 新聞等」 (86.7\%)の回答が最も多かった. 各大学薬学部主催の卒 後教育の利用はわずか16件 $(4.4 \%)$ にすぎなかった (Fig. 3). 自己研鑽の方法として最も回答の多かった 「各種団体, 大学薬学部による講演会」に関して「満足」 との回答が38\%であるのに対して，「不満」もしくは「少 し不満」との回答は計 $60 \%$ であった $($ Fig. $4 \mathbf{A})$.これら 回答者の不満の内訳は, 男女ともに「個人的理由で時間 が合わない」が最も多く, 続いて「業務による時間的制 約」,「講演会場まで行くのが面倒」,「自分の知りたい情 報がない」が主な理由であった(Fig. 4B).

3 ）将来の薬荗師卒後教育に関するアンケート調査 薬剤師卒後教育の新たな教育媒体に関する質問では, 男性はすべての年代で, 女性に打いても50代を除くすべ ての年代で $60 \%$ を超える回答率で「インターネット」の

1．現在の薬剤師卒後教育に関する質問

(1) 薬剂師として業務を続けていく上で自己研鑽は必要か?

(2) 現在実施している自己研鑽の具体的方法とは?

(3) 現在実施されている講演会形式の卒後教育に対する満足度及び不満の理由

2. 将来の薬剂師卒後教育に関する質問（現行の米国Continuing

Educationを参照にして)

(1) 卒後教育の新たな教育媒体として期待するものは?

(2) 無料のインターネット教育サイトに対する関心度

(3) 薬学部に望む卒後教育とは?（米国医療系大学が現在実施している専門家 養成講座に対する関心度)

3. 薬剤師免許制度に関する質問

(1) 薬学部 6 年制の導入に対する意識調查

(2) 専門薬剂師資格制度への関心度

(3) 日本の薬剂師免許制度と薬剂師継続教育の義務化について

Fig. 1. 薬剤師卒後教育に関するアンケート調査項目 
Table 1. 日米間の薬剂師免許制度の現状

\begin{tabular}{|c|c|c|}
\hline & 日本 & 米国（オハイオ州） \\
\hline $\begin{array}{l}\text { 免許取得に要す } \\
\text { る専門教育年数 }\end{array}$ & 4 年 & $\begin{array}{c}6 \text { 年 } \\
(2001 \text { 年より })\end{array}$ \\
\hline $\begin{array}{c}\text { 薬剂師免許 } \\
\text { 受験資格 }\end{array}$ & 薬学士 & Pharm.D. \\
\hline 交付 & 厚生労働省（国） & $\begin{array}{l}\text { State Boards of Pharmacy } \\
\text { (州薬局委員会) }\end{array}$ \\
\hline 更新期間 & 変更届けのみ（終身免許） & 3 年 \\
\hline 卒後教育 & 任意 & $\begin{array}{c}\text { 更新に必須 } \\
\text { ACPE 承認を受けたた主催団体による } \\
\text { 教育を合計 } 60 \text { O時間以上 ( } 3 \text { 年間) }\end{array}$ \\
\hline
\end{tabular}

Table 2. 米国における各種卒後教育，研修制度ならびに その支援団体一覧

\begin{tabular}{|c|c|c|c|}
\hline & 名称 & 認定団体 & 認定の種類 \\
\hline $\begin{array}{c}\text { 卒後研修制度 } \\
\text { (任意) }\end{array}$ & $\begin{array}{c}\text { Residency（臨床研修） } \\
\text { Traineeship（特殊臨床専門職養成） } \\
\text { Fellowship（臨床研究研修） }\end{array}$ & $\begin{array}{c}\text { ASHP, APhA, AMCP, ASCP } \\
\text { ASHP,ASCP,ACA } \\
\text { AACP,ACCP }\end{array}$ & 各課程修了の認定 \\
\hline $\begin{array}{c}\text { 専門資格 } \\
\text { (任意) }\end{array}$ & $\begin{array}{l}\text { Specialty（専門薬剤師認定資格） } \\
\text { Non-specialty } \\
\text { Disease management（疾患管理薬剤師） } \\
\text { Multidisciplinary（各種疾患療法専門資格） }\end{array}$ & $\begin{array}{l}\text { BPS（各種専門職認定） } \\
\text { CCGP（老年病のみ） } \\
\text { NISPC } \\
\text { CDE, various }\end{array}$ & $\begin{array}{c}\text { 履修・試験合格による } \\
\text { 資格認定 }\end{array}$ \\
\hline 継続教育制度 & $\begin{array}{c}\text { Continuing Education } \\
\text { (継続教育) } \\
\text { Certificate program } \\
\text { (各種治療法専門家養成講座 })\end{array}$ & $\begin{array}{l}\text { ACPE } \\
\text { ACPE }\end{array}$ & $\begin{array}{c}\text { 任意課題、免許更新に必須 } \\
\text { 特定課題:履修、試験合格 } \\
\text { 必要 }\end{array}$ \\
\hline
\end{tabular}

AACP: American Association of Colleges of Pharmacy

ACA: American College of Apothecaries

ACCP: American College of Clinical Pharmacy

ACPE: American Council on Pharmaceutical Education

AMCP: Academy of Managed Care Pharmacy

APhA: American Pharmaceutical Association

ASCP: American Society of Consultant Pharmacist

ASHP: American Society of Health-System Pharmacist

BPS: Board of Pharmaceutical Specialties

CCGP: Commission for Certification in Geriatric Pharmacy

NCBDE: National Certification Board for Diabetes Educators

NISPC: National Institute for Standards in Pharmacist Credentialing (www.aacp.org)

*和名称は仮訳である。

(www.acaresourcecenter.org)

(www.accp.com)

(www.acpe-accredit.org)

(www.amcp.org)

(www.aphanet.org)

(www.ascp.com)

(www.ashp.org)

(www.bpsweb.org)

(www.ccgp.org)

(www.ncbde.org)

(www.nispcnet.org)

\section{A 性別}

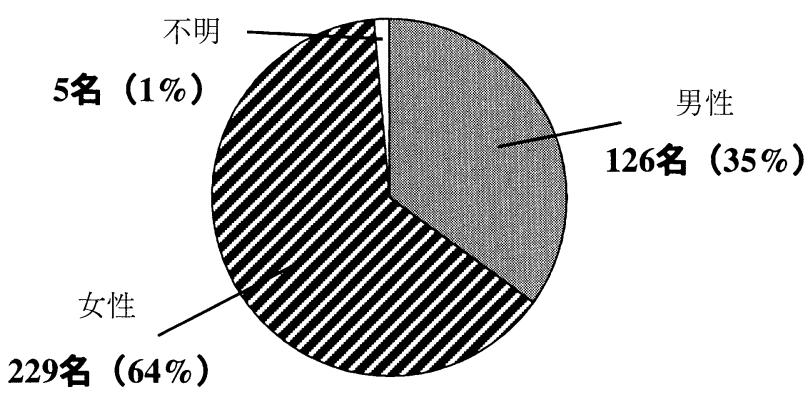

B 年齢別 不明

5名 $(1 \%)$

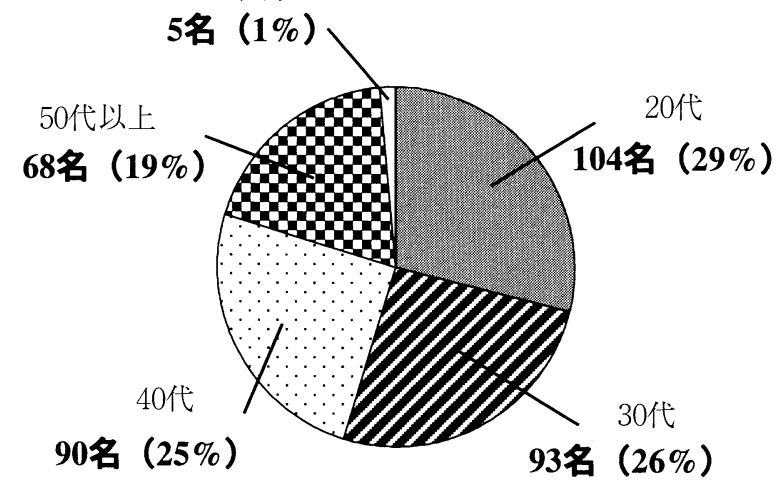

Fig. 2. アンケート回答者の背景分析 


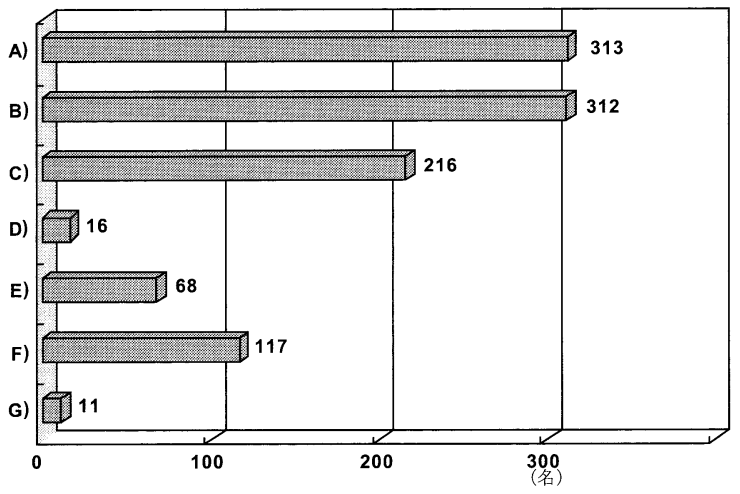

Fig. 3. 現在の薬剤師卒後教育に関するアンケート 調査 (1)一現在実施している自己研鑽の方法 A）病院薬剂師会等による講演会等，B）医療 系専門雑誌, 新聞等, C) 部内, 薬局内勉強会, D) 大学薬学部主催の卒後教育, E) 学会参加, F）インターネットの医療系サイト，G）その 他

利用に最も関心が集まった。また，特に30代，40代の女 性の「インターネット」への関心度が高い值を示した (Fig. 5 ). さらに米国に拈いてすでに実施，利用されて いるインターネット無料教育サイトに関して，男女とも にいずれの年代でも「非常に興味がある」もしくは「興 味がある」が95\%を超えた(Fig. 6$)$ ．同様に卒後教育の 一環として米国の大学医療系学部で実施されている治療 専門家養成課程については，「オンライン通信講座を受 講してみたい」との回答が男女それぞれ42.1\%，32.1\% であった。また，このような積極的回答は年齢依存的に
減少しているのに対し，「受講したいが難しい」という 消極的回答が40代，50代では積極的回答を上回った。 「受講したくない」もしくは「必要ない」の否定的回答 は非常に少数であり，特に 20 代，30代にはまったく見ら れなかった(Fig. 7$)$.

4 ）薬剤師免許制度に関するアンケート調査

薬学部 6 年制に関しては,「危機感」,「不安感」を感 じるといった回答は年齢依存的に減少し，20代では半数 を超える回答者が何らかの不安を感じていることが判明 した(Fig. 8). 専門薬荗師資格に関しては男女ともいず れの世代でも非常に高い関心度を示し，特に20代，30代 で「是非獲得したい」，「出来れば挑戦し，獲得したい」 の積極的回答が各々 $86.5 \%, 86.1 \%$ でった (Fig. 9$)$.

現在の日本の薬剂師免許制度と薬剤師卒後教育制度の 在り方に関する質問で「何らかの薬剤師卒後教育の制度 化が必要」との回答が $83 \%$ あ゙あた.さらにその内の $13 \%$ は「免許更新制度を採り入れ，薬剤師卒後教育制度を米 国同様に義務化すべき」との回答であった（Fig. 10）。一 方，「薬剤師卒後教育の義務化の必要性」については $86 \%$ が「必要ない」もしくは「反対」との回答であった。

\section{考察}

米国では薬剤師免許証の交付は州毎に行われ，免許更 新制度も州毎に異なる。全米共通制度として，2001年よ り薬剂師免許受験資格を Pharm.D. (Doctor of Pharmacy) 取得者と定め, 6 年間の大学薬剤師養成課程で教育を受

\section{A 満足度}

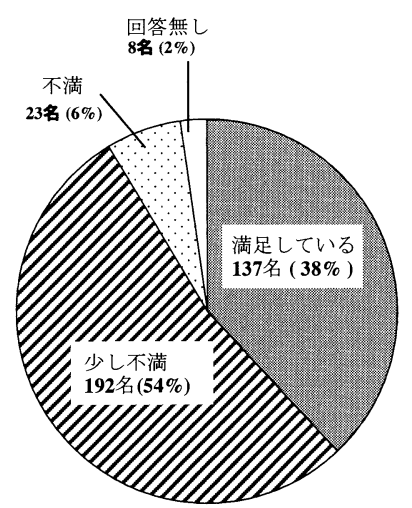

B 不満の内訳

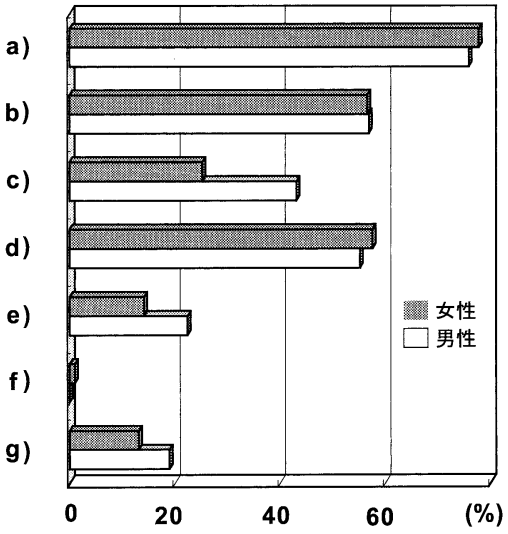

Fig.4. 現在の薬剤師卒後教育に関するアンケート調査 $(2)$ 一現在 実施されている講演会形式に対する意識分析

（A）満足度（B）不満の内訳；a）個人的な理由で日程，時 間が合わない，b）業務による時間的制約(講演時間帯が勤 務時間等)，c）自分の知りたい情報が少ない，d）講演会場 まで行くのが面倒，e）実際の業務に役立たない，f）講演 を聴くのが面倒, g) その他 


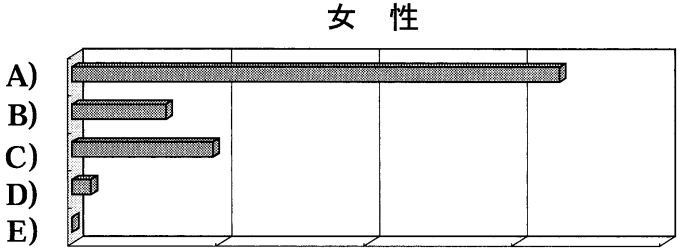

A)

B)

C)

D)

E)

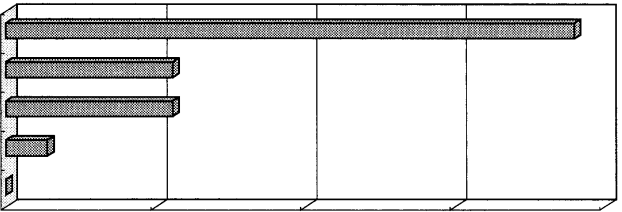

A)

B)

C)

D)

E)

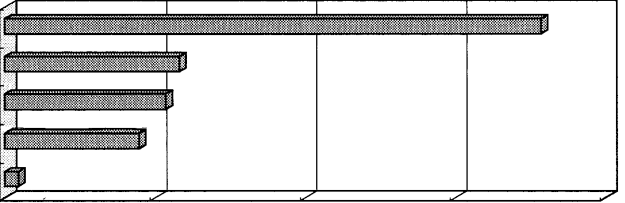

A)

B)

C)

D)

E)

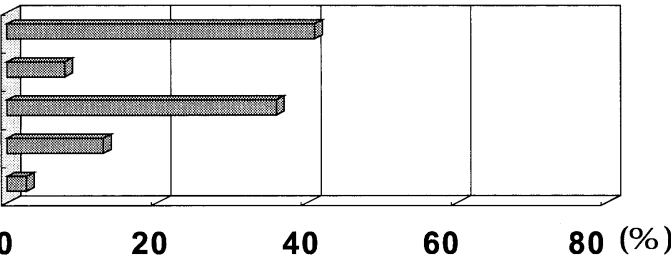

男 性

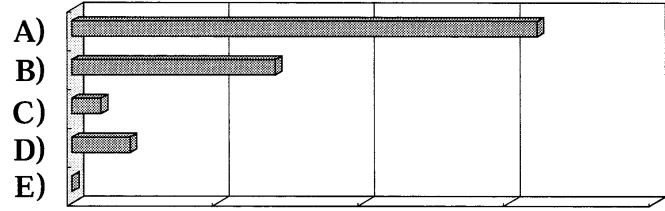

A)

B)

C)

E)

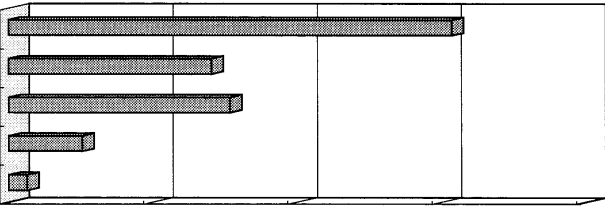

A)

B)

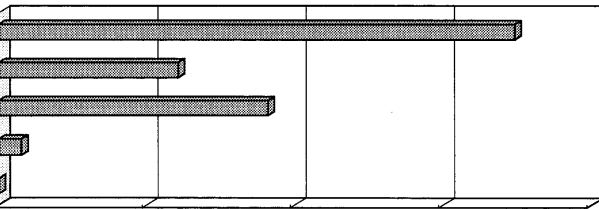

D)

E)

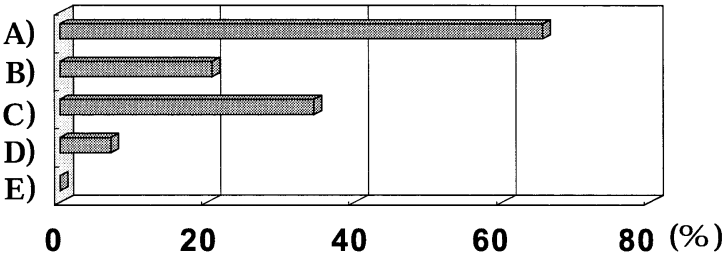

Fig. 5. 将来の薬剤師卒後教育に関するアンケート調査(1)一「将来の日本の薬剤師 卒後教育の新たな教育媒体として期待するものは?」

A）インターネットを利用したオンライン通信教育，B）メールマガジン，

C）講演会ビデオ, D）講演会テープ(音声) +スライド要旨, E）その他

A 性別比較

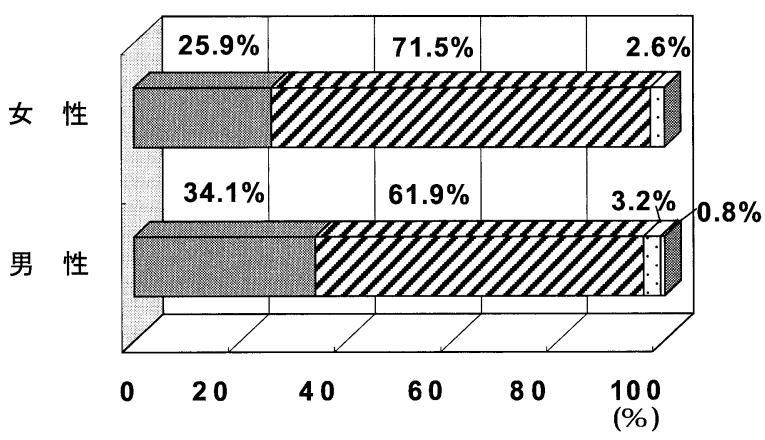

B 年齢比較

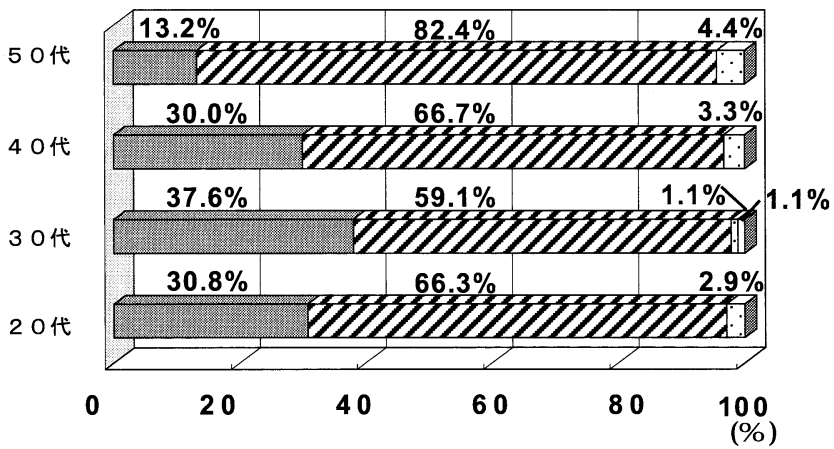

$\square$ 非常に興味がある(もし日本語で利用可能ならば利用する)

】 興味はある(あれば利用するかもしれない)

$\because \because$ あまり興味ない

$\square$ 絶対利用しない

Fig. 6. 将来の薬片師卒後教育に関するアンケート調査 $(2)$ 一米国で実施されている無料のインターネット講 演サイトに対する関心度

けた者しか薬剤師資格を得ることは出来なくなった。ま た，オ八イオ州では他州と同様に薬剤師免許の更新制度 を採用しており， 3 年毎の更新が義務づけられている。
更新に際しての薬剤師継続教育 (Continuing Education)義 務化も他州と同様である．各個人の自由意志により行わ れる日本の薬剤師卒後教育とは異なり，米国での薬剂師 
A 性別比較

A)

B)

c)

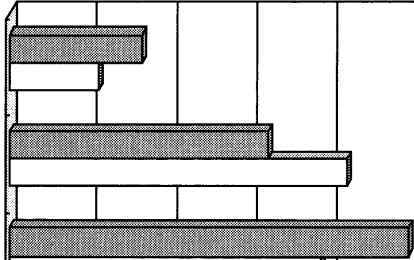

D)

E)

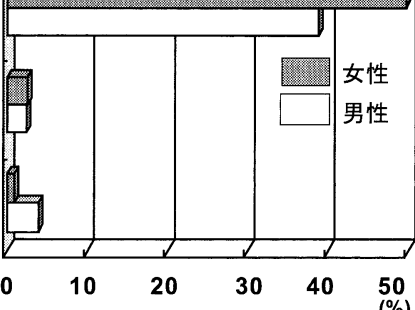

B 年龄比較

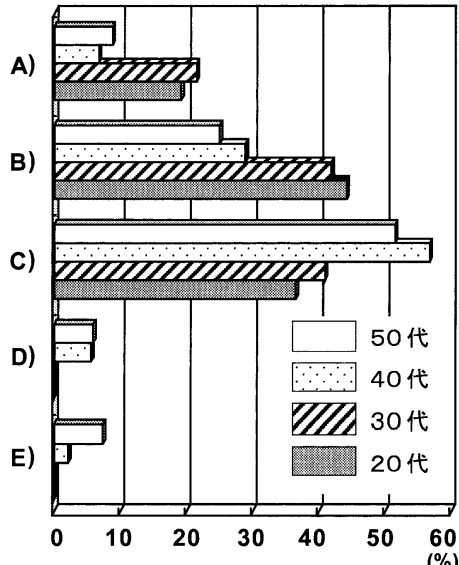

Fig. 7. 将来の薬剂師卒後教育に関するアンケート調查 (3)一「米国の大学で実施され ている治療専門家養成講座(講義参加型もしくはオンライン通信講座) が日本 の大学で実施された場合あなたはどうしますか？」

A) 講義参加型へ挑戦してみたい，B）オンライン通信講座へ挑戦してみたい,

C）挑戦したいがいずれも難しい，D）受講したくない，E）受講する必要は ない

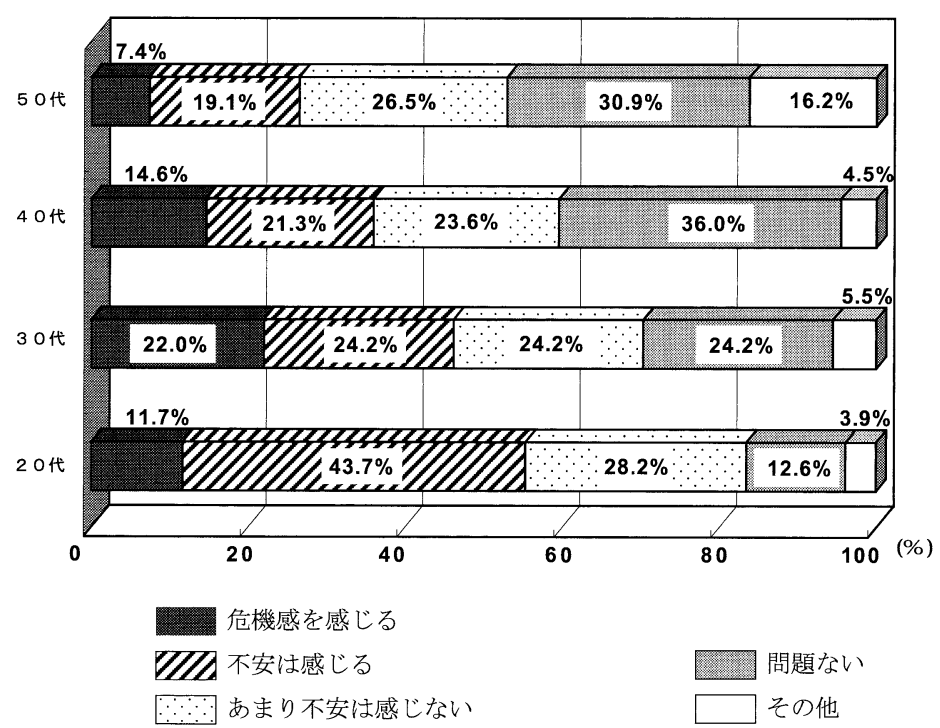

Fig. 8. 薬剤師免許制度に関するアンケート調査 (1) 一将来の薬学部 6 年制に対する意識調査

免許の維持，更新に必須とされる薬剂師継続教育は,

ACPE (American Council on Pharmaceutical Education)の 承認を受けた主催団体による教育を 3 年間で 60 時間以上 受けることと定められている3 $($ Table 1$)$.ここのような厳 しい制度の存在が米国薬剤師教育レベルを支えていると いっても過言ではない.さらにこの制度を維持するため に，さまざまな組織・団体が薬剤師の自己研鑽を援助す るための教育，研修ならびに資格認定を提供している

(Table 2 ).

このような米国薬剤師教育システムと比較し，日本の 卒後教育は立ち後れているといわざるを得ない. 特に愛
媛県は薬学部を有する大学が存在せず，愛媛県内におい て薬剤師卒後教育として公に実施されるものは都市部よ りも少なく，愛媛県は卒後教育の機会には恵まれない地 域の一つであることは否めない。しかしながら，回答者 全員が「自己研鑽による卒後教育は必要」と回答してい るように卒後教育に対する関心度は非常に高い. 一方, その自己研鑽手段として最も回答の多かった「講演会等 の勉強会」に対して，多くの現役薬剤師は何らかの不満 を抱えていることも判明した。特に，業務・個人的な理 由による時間的制約から「講演会に参加したくても出来 ない」といった不満が最も多く，「自分の知りたい情報 
A 性別比較

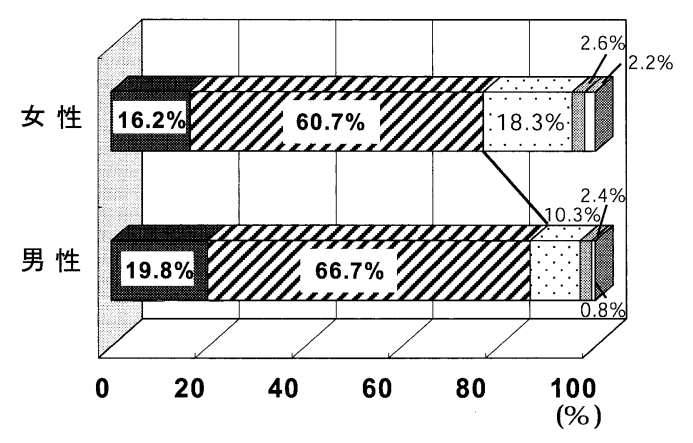

是非獲得したい V】】時間があれば挑戦し、
B 年齢比較

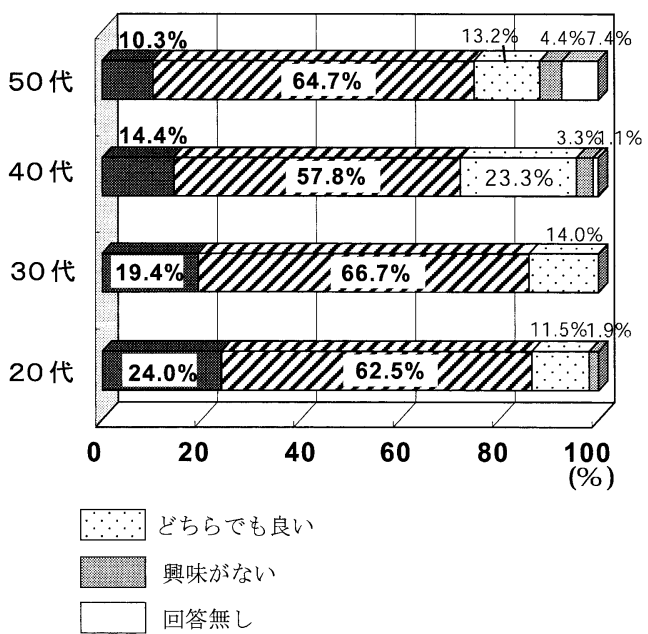

Fig.9. 薬剂師免許制度に関するアンケート調査 $(2)$ 一「専門薬剤師資格制度が導入された場合 あなたはどうしますか?」

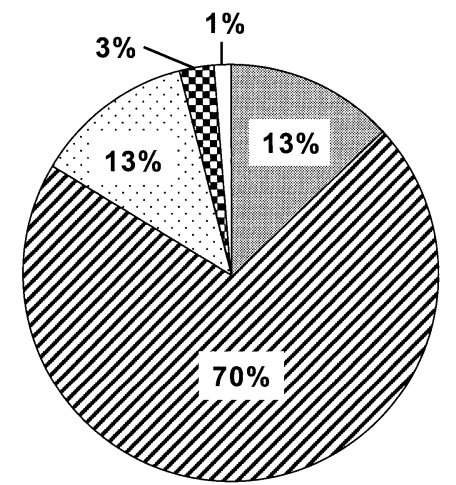

薬剂師全体のレベルアップのため、免許更新並びに 薬剤師継続教育の義務化は必要である

D何らかの薬剂師継続教育制度は必要と思うが、免許 更新の義務化にする必要はない

薬戍師としての知識習得・教育に関しては個人の自 主性に任せるべきである

$\mathbf{8 8 8}$ 現状のままで良い 回答無し

Fig. 10. 薬椷師免許制度に関するアンケート調査 (3) 一薬剂師免許更新制度と薬剂師卒後教 育義務化について

が少ない」，「業務に役立つ情報が少ない」といった意見 も目立っていた。これは多忙な業務に追われている現役 薬剤師は短時間で，効率的に，有用な情報を得たいが実 現できないということを反映しているものと思われる. 米国では，このような薬剤師が抱える問題を解消するた めのさまざまな卒後教育の工夫が提案，実践されてい る。それは個々の受講者が時間に縛られず，テーマを選 択して学ぶ方法, すなわちインターネット等の電子媒体
を用いた教育方法である。今回のアンケート調査結果か らも判明したように，現在米国で薬剤師継続教育に利用 されているインターネット等の電子媒体を利用した卒後 教育を受けてみたいという回答が非常に多く，特に20～ 40代に至る女性に関心が高いことが示唆された。これ は，「日本の既婚女性」の多くが多忙な家事をこなさな ければならず，自己研鑽のために特別に時間を割くこと が困難 ${ }^{4}$ なこと，パーソナル・コンピューターの普及, 自由な時間選択やテーマ選択が可能なことならびにイン ターネットの簡便性といった面からこれらの世代の女性 に支持されたのではないかと考える. 現在，すでに日本 でもいくつかの医療系インターネット教育サイトは公開 されている。しかしながら，これら教育サイトは有料で あり,かつ非常に高価な登録料が必要である.そのため, 気軽に利用しにくいのが現状である。米国で公開されて いる薬剤師継続教育サイトは広く薬剂師に利用を促すた めに，製薬企業との協賛等により，その登録料および利 用料が無料のサイトが多く存在している。もしこのよう な教育サイトが日本語で利用可能な場合，「利用してみ たい」との回答が全回答者の95\%を超えるほどであっ た。米国のような教育サイトの運営方法であれば十分利 用者も見込まれ，日本でも開設価值があると思われるこ とから，その開発が大いに望まれるところである。

米国ではさまざまな大学医療系学部に糖尿病, 抗凝固 療法, 高脂血症, 喘息等の慢性疾患治療を対象とした専 門家養成講座 (Certificate Program) が卒後教育課程として 存在し(Table 2), いくつかの大学ではインターネット およびメール通信を利用したオンライン通信教育講座が 開講されている。この通信講座は米国に扔いて医療専門 
家の教育レベルの地域較差の是正に多大な貢献をしてい ると思われる。このシステムに関する今回のアンケート 結果においても「オンライン通信講座」への関心は高く, やはり現役薬剤師がインターネットによる教育方法に強 い関心を有していることが示唆された．特に20～30代の 若い世代はこのようなインターネットを利用した教育方 法に対して積極的な回答が多い.これは薬学部 6 年制へ の移行に対して何らかの不安を感じていることによると 思われる，若い世代が卒後教育に対して積極的であるこ とは，薬剤師界にとって心強い．その意欲を消失させな いためにも現在の受動的教育方法から，自ら知識・技術 の習得を試み，自己研鑽を積むための能動的教育方法5) への展開，さらにインターネット等を利用した能動的教 育方法の開発(各種薬物療法等に関する通信教育講座の 開設)ならびに専門薬剤師資格制度の早期実現が望まれ る.

さらに現在の日本における薬剂師卒後教育の大きな問 題点として，卒後教育の個人自主性主義がある。日本に は薬剂師免許の維持には一切の教育義務はなく, 更新の 必要性すらない。そのため, 時間が経てば経つほど, 各 個人間に専門知識のレベル較差が生じてしまうのは無理 もないことである。薬剤師業務・医療知識を一定の高い レベルで維持するにはやはり何らかの卒後教育制度が必 要と思われる。しかしながら，現在の受動的教育方法を 用いた卒後教育のみでは，一部に不公平が生じてしまう のは否めない．卒後教育義務化制度に関するアンケート 調査において，多くの回答者が義務化に否定的であった 原因も，受動的方法による卒後教育に対する不満もしく は不公平感がその要因になっていると思われる。その不 公平感を是正するためにもインターネット利用による能 動的教育方法の開発および卒後教育機会の推進は極めて 重要なテーマである。この点に関して, 特に病院薬剤師 会や各大学薬学部主催による卒後教育の在り方を再考す べきではなかろうか. 現在の講演形式中心の教育方法に 比ベ，インターネットを利用した通信教育講座は, 講座 開設者側には, 受講者の拡大といった利点があり, 受講 者側にも, 時間的, 地理的簡便性といった利点が考えら れ，受講者である薬片師に広く支持されるであろう。今 後の卒後教育へのさらなるインターネット利用が強く望 まれる。また, 愛媛県病院薬剂師会でも能動的卒後教育
の試みとして, 小グループ毎の腫瘍専門薬剂師育成研修 会を検討している。こうした卒後教育機会の整備を行っ た後, 薬剤師全体の教育レベルの底上げ，教育レベルの 個人較差と地域較差是正のために, 薬剂師免許更新制度 およびそれに伴う卒後教育の義務化も必要ではないかと 考える。

今回のアンケート調查は愛媛県病院薬剤師会員を対象 にしたものである.したがって，われわれの得た調査結 果は, 日本における一地域の薬剤師卒後教育の問題とも いえる.しかしながら, 愛媛県は, 平成14年次厚生労働 省統計では人口 10 万人たりの薬剤師数(全国平均 121.3 人に対して愛媛県 120.3 人)は日本に扮ける平均的地域と いえる.さらに, 日本全国に扮ける薬局・医療施設従事 者に関する薬剤師年龃構成 (20代: $21.3 \%, 30$ 代: $24.6 \%, 40$ 代: $25.9 \%, 50$ 代: 17.0\%), および男女比 (男性：39.5\%, 女性：60.5\%) と今回のアンケート回答 者構成が非常に近似している。したがって, 今回の調査 結果より得られた結果は愛媛県のみならず, 日本の薬剤 師全体の問題点ならびに改善点を反映するものであると 考える.

謝辞 本調查研究は平成15年度厚生労働科学研究補助金に よる米国研修に基づくものである。その研修に際し，貴重な ご意見をいただいた米国クリーブランド・ルイス・ストーク ス退役軍人病院のマシュー・A・フォラー博士, 日本病院薬郕 師会の全田浩会長および国際交流委員会委員長である名古屋 大学医学部附属病院の鍋島俊隆教授に赤心より感謝申し上げ ます。

\section{引用文献}

1) 渡辺徹, 薬学教育 6 年制をめぐって一6者懇の流れ を中心に一, 月刊薬事, 43, 1459-1462 (2001).

2) 瀬沼香代子, S.R. カイザー，寺澤孝明，米国の薬 学教育一カリフォルニア州の例を中心に, 月刊薬 事, 43, 1503-1507 (2001).

3) Ohio State Board of Pharmacy Continuing Pharmacy Education Changes, The Ohio State Board of Pharmacy News, 23, 1-4 (2002).

4）星川みのり，薬剤師の資質向上のための生涯研修の 進め方，月刊薬事，43，1701-1704 (2001).

5) 平井正巳, 能動的研修を目的とした PC 検討会, 月 刊薬事, 43, 1695-1699 (2001). 